УДК: 615.322:547.466:582.284:543.544.5.068.7

DOI: 10.15587/2519-4852.2018.141412

\title{
THE RESEARCH OF FREE AMINOACIDS OF WATER-SOLUBLE PROTEIN-POLYSAC- CHARIDE COMPLEX OF OYSTER MUSHROOM PLEUROTUS OSTREATUS
}

\author{
(C) B. Varinsky, N. Kucherenko, O. Kolpakova
}

Останнім часом на фармаџевтичному ринку України збільшується частка лікарських засобів природного походження. Це пов'язано з тим, щзо фармакологічний ефект природних субстанцій забезпечує комплекс біологічно активних речовин, щуо має високу терапевтичну дію та мінімальну кількість побічних реакцій. Тому дослідження хімічного складу та стандартизація природних субстанцій є важливим етапом фармацевтичних досліджень.

Перспективним джерелом отримання активно діючих інгредієнтів є гриб Плеврот черепичастий. Хімічний склад изього гриба представлено великою кількістю біологічно активних речовин, щзо забезпечують його багатогранне використання в народній медицині.

Мета. Визначення якісного та кількісного складу вільних амінокислот, щуо входять до складу водорозчинного білково-полісахаридного комплексу (ВБПСК) грибу Плевроту черепичастого.

Методи. Для дослідження діючих субстаниій природного походження найбільи часто використовують фізико-хімічні методи. Це пов'язано з тим, щзо вони забезпечують високу інформативність, точність, ефективність та відтворюваність. Для аналізу амінокислотного складу ВБПСК грибу Плевроту черепичастого було використано метод високоефективної рідинної хроматографії (ВЕРХ), ияо є заснованим на розділенні індивідуальних компонентів за рахунок різної адсорбиійної здатності.

Результати дослідження. Дослідження амінокислотного складу ВБПСК грибу Плевроту черепичастого показало, щуо комплекс містить 10 (7 \%) вільних амінокислот, серед яких 5 є незамінними. Виявлені амінокислоти є сполуками аліфатичної, гетерочиклічної та ароматичної будови. Їх представлено гліцином, аланіном, лейцино, ізолейцином, треоніном, селіном, лізином, аргініном, гістидином та фенілаланіном.

Висновки. В ході експериментальних досліджень було встановлено якісний та кількісний склад вільних амінокислот ВБПСК грибу Плеврот черепичастий. Запропоновано методику визначення та розділення вільних амінокислот методом високоефективної рідинної хроматографії. Отримані результати пропонуються для стандартизації вихідної субстаниії в процесі виробництва лікарських препаратів на основі ВБПСК грибу Плевроту черепичастого

Ключові слова: Плеврот черепичастий, біологічно активні речовини, амінокислоти, високоефективна рідинна хроматографія, стандартизація

\section{Introduction}

Natural herbal medicines are very popular with people around the world. This is due to the fact that complexes of biologically active substances of natural origin provide high efficiency and insignificant number of side effects.

One of the main trends in the study of substances of natural origin is the study and standardization of the chemical composition of substances that provide biological activity [1].

2. Formulation of the problem in a general way, the relevance of the theme and its connection with important scientific and practical issues

Natural active substances are multicomponent mixtures, the qualitative and quantitative composition of which can vary not only in the process of ontogenesis of the plant organism, but also as a result of the technological process of obtaining, processing and storing raw materials, isolated from it substances and medicines created on their basis. Therefore, recently, the requirements for quality of both plant raw materials and phytopreparations have been raised. In this regard, an important stage in the production of medicines is the development of methods for standardizing biologically active substances of natural origin that will be able to provide the predicted therapeutic effect of medicines created on their basis [2].
3. Analysis of recent studies and publications in which a solution of the problem are described and to which the author refers

The search and creation of environmentally friendly, safe and renewable sources of physiologically active substances is an extremely important task of pharmaceutical research. In this regard, higher basidium fungus attract attention as producers of a wide range of biologically active components [3].

A promising raw material for obtaining on its basis highly effective medications is the oyster mushroom Pleurotus ostreatus. The composition of this fungus includes a large number of biologically active substances that provide its many-sided use in folk medicine $[4,5]$.

For use in medical practice and food industry, a substance was developed for the protein-polysaccharide complex [6]. The active substance of this substance is a water-soluble protein-polysaccharide complex (WPPSC) of the Pleurotus ostreatus fungus. In previous studies, the standardization of the polysaccharide part of the complex was carried out and the study of the composition of its protein-amino acid portion began [7].

In the arsenal of modern pharmacy there are a large number of methods that make it possible not only to identify the composition of vegetable substances, but also to divide and quantify individual components. The most popular in this direction are physico-chemical 
methods that are highly sensitive, are sufficiently informative and capable of providing the required accuracy of results $[2,8]$.

Analysis of literary data shows that the most effective method of studying the composition of natural substances is chromatography, which allows to identify the chemical structure of the substance $[8,9]$. That is why, for the study of the amino acid composition of complexes of biologically active substances, highly effective liquid chromatography has been used recently $[10,11]$.

4. The field of research considering the general problem, which is described in the article

To date, the unidentified composition of the amino acid part of the WPPSC of the Pleurotus ostreatus fungus. This study is devoted to the investigation of the content of free amino acids in the substance.

\section{Formulation of goals (tasks) of article}

The aim of the study was to determine the free amino acids that are part of the WPPSC of the Pleurotus ostreatus by the method of high-performance liquid chromatography.

6. Presentation of the main research material (methods and objects) with the justification of the results

During the study, the method of high-performance liquid chromatography (HPLC) was used. This method is widespread for the separation of multicomponent mixtures of biologically active substances of natural origin $[12,13]$.

HPLC is a type of liquid chromatography and is based on the separation of individual components between two phases - moving and stationary. The mobile phase (eluent) is a liquid, the main characteristics of which are composition, ionic strength, $\mathrm{pH}$ and other indicators, immovable - a sorbent with a small grain size. Thus, the analysis of the complex of substances occurs by separation in the flow of the mobile phase due to different interaction with the sorbent. The choice of the phases, their characteristics and the conditions of the experiment depends on the properties of the investigated sample [10, 13].

For the study of free amino acids, which are part of the WPPSC of the Pleurotus ostreatus fungus, with the HPLC method used an LCMS device (Agilent 1260 InfinityHPLCSystem) equipped with a degasser, a binary pump, an autosampler; one-squadron mass spectrometer Agilent 6120 with ionization in electric field (ESI); software OpenLABCDS Software and the ZorbaxRX-SIL (1.8 $\mu \mathrm{m}, 4.6 \mathrm{~mm} \times 50 \mathrm{~mm}$, Agilent) column with a protective filter.

The amino acid analysis was carried out under the following conditions: gradient mode using a buffer solution: $\mathrm{A}-\mathrm{H}_{2} \mathrm{O}(\mathrm{HCOOH} 0.1 \%)$ and a solution of the organic modifier: $\mathrm{B}-\mathrm{CH}_{3} \mathrm{CN}(\mathrm{HCOOH} 0.1 \%$ ), flow rate $0.4 \mathrm{ml} / \mathrm{min}$, injection of $10 \mu \mathrm{l}$, column temperature of $40^{\circ} \mathrm{C}$.

When identifying amino acids, the ratio $\mathrm{m} / \mathrm{z}$ (mass to ion charge) was used, which coincided with the molecular masses of the quasimolecular ion $(\mathrm{M}+1)$. The quantitative content of amino acids was calculated based on the plane of the peaks of the investigated solutions and solutions of comparison with the chromatograms of the isolated ions.

The comparison solution was prepared in the following way. First, we obtained an initial solution of each amino acid at a concentration of $0.01 \mathrm{~g} / \mathrm{ml}$. Then, $50 \mu \mathrm{l}$ of the initial solution was mixed for 14 amino acids

The production of the test solution was carried out as follows: weighing $0.02 \mathrm{~g}$ of protein polysaccharide complex, dissolving in $1 \mathrm{ml}$ of water, processing in an ultrasonic bath for 15 minutes at $50^{\circ} \mathrm{C}$, adding $1 \mathrm{ml}$ of acetonitrile to precipitate proteoglycans, centrifuging at $15000 \mathrm{rpm}$ for $10 \mathrm{~min}$, filtered through a nylon filter.

Chromatograms for isolated ions at $\mathrm{m} / \mathrm{z} 76,176$, $156,90,166,147,120$ solutions of the comparison and the test solution corresponding to the amino acids glycine, arginine, histidine, alanine, phenylalanine, lysine, threonine, are shown in Fig. 1-14 respectively.

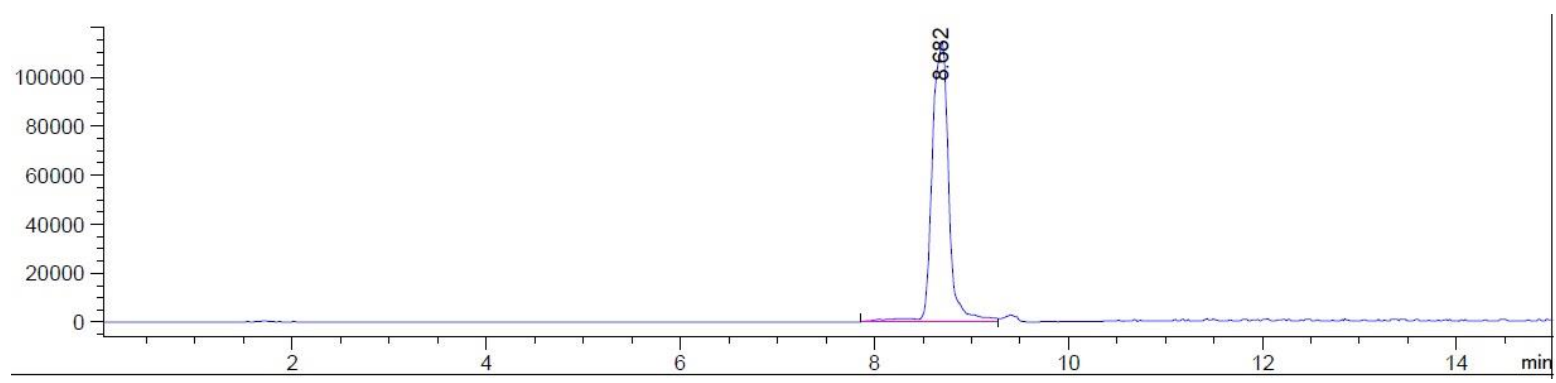

Fig. 1. Chromatogram of glycine (comparison solution)

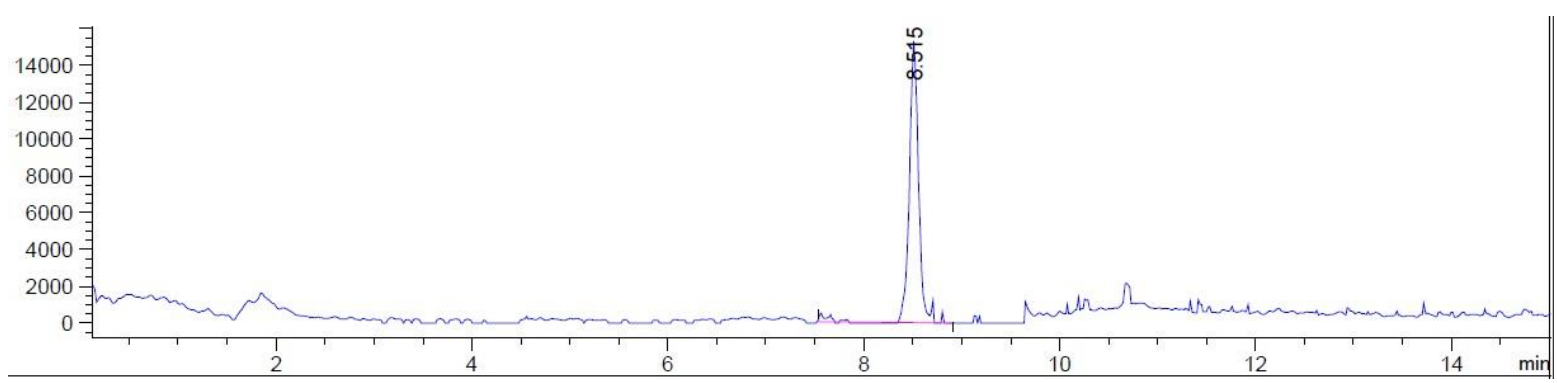

Fig. 2 Chromatogram of glycine (WPPSC of Pleurotus ostreatus fungus) 


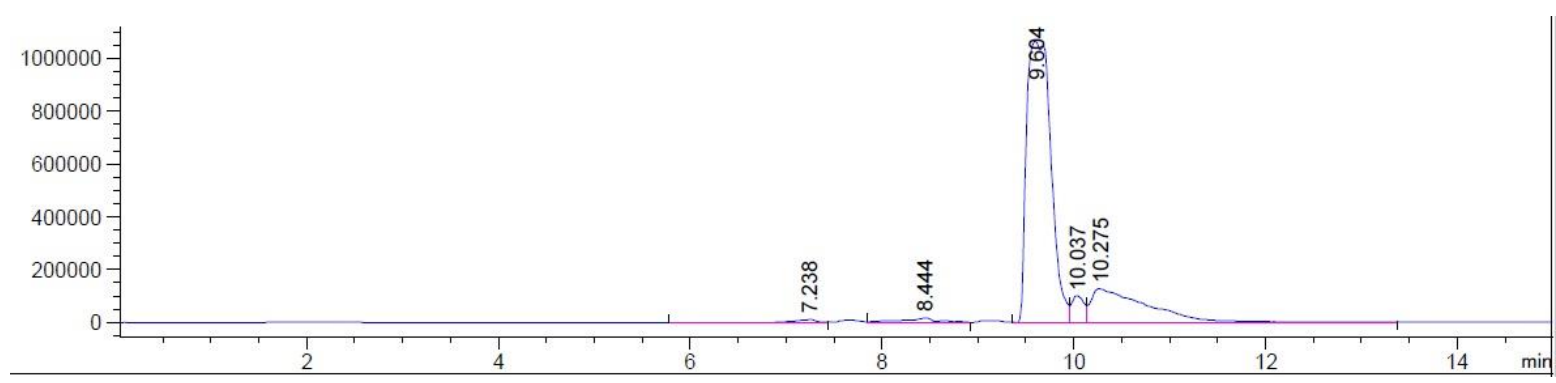

Fig. 3. Chromatogram of arginine (comparison solution)

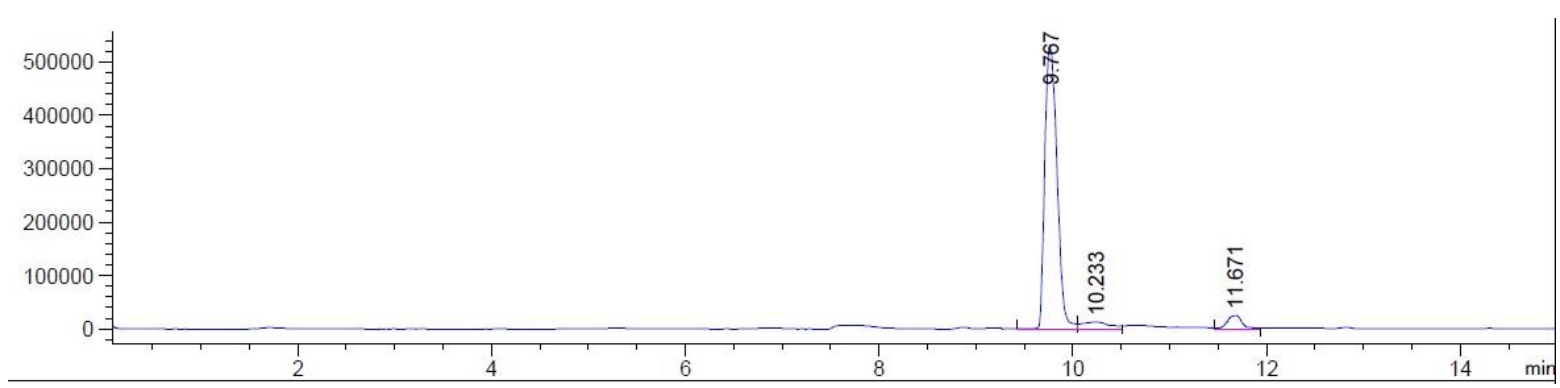

Fig. 4. Chromatogram of arginine (WPPSC of Pleurotus ostreatus fungus)

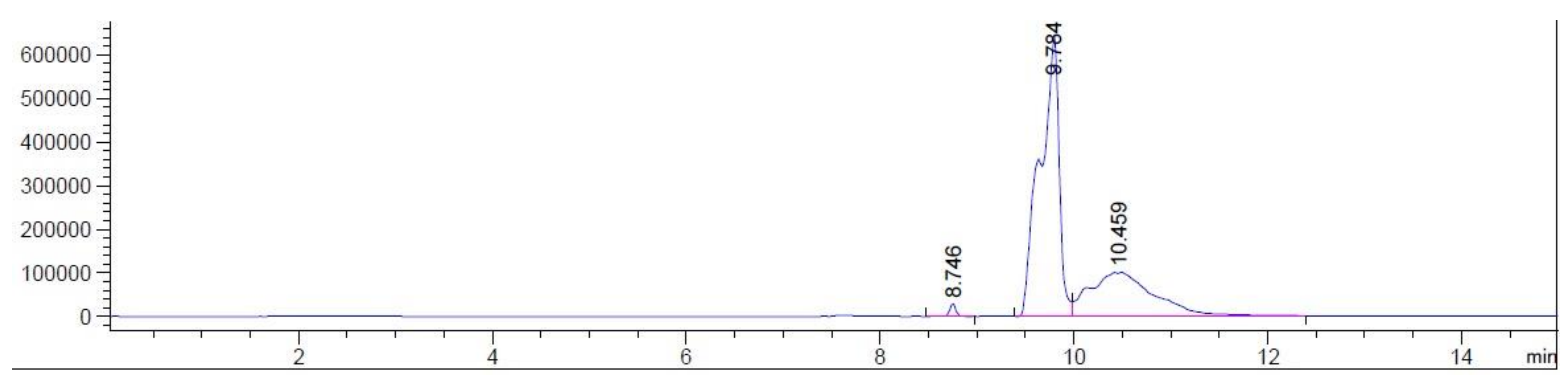

Fig. 5. Chromatogram of histidine (comparison solution)

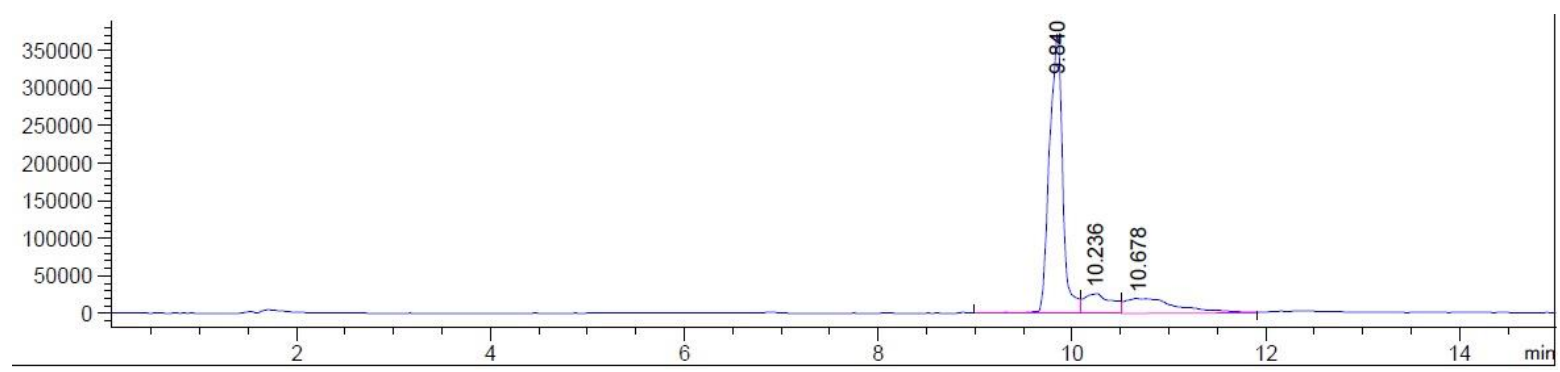

Fig. 6. Chromatogram of histidine (WPPSC of Pleurotus ostreatus fungus)

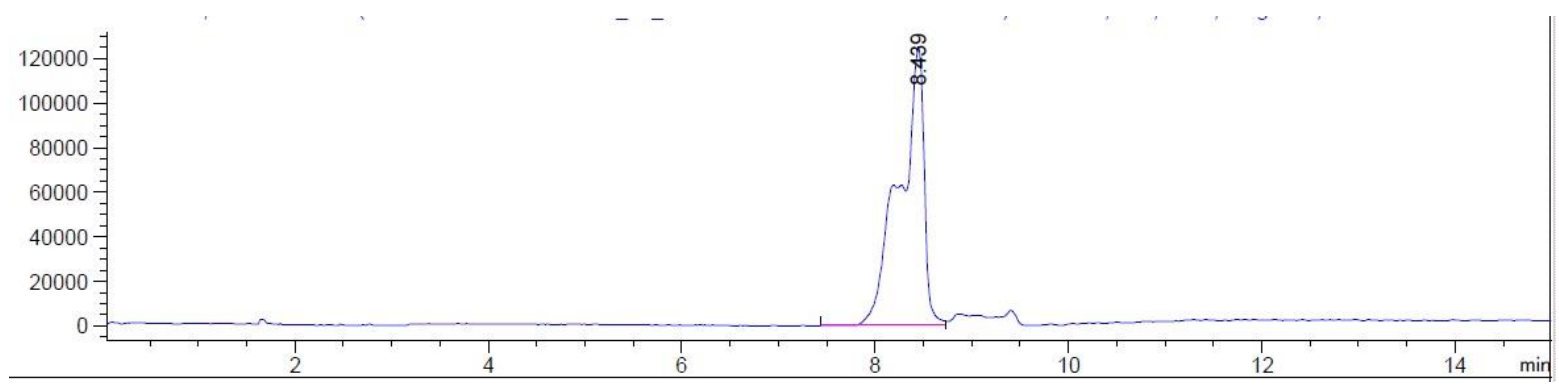

Fig. 7. Chromatogram of alanine (comparison solution) 


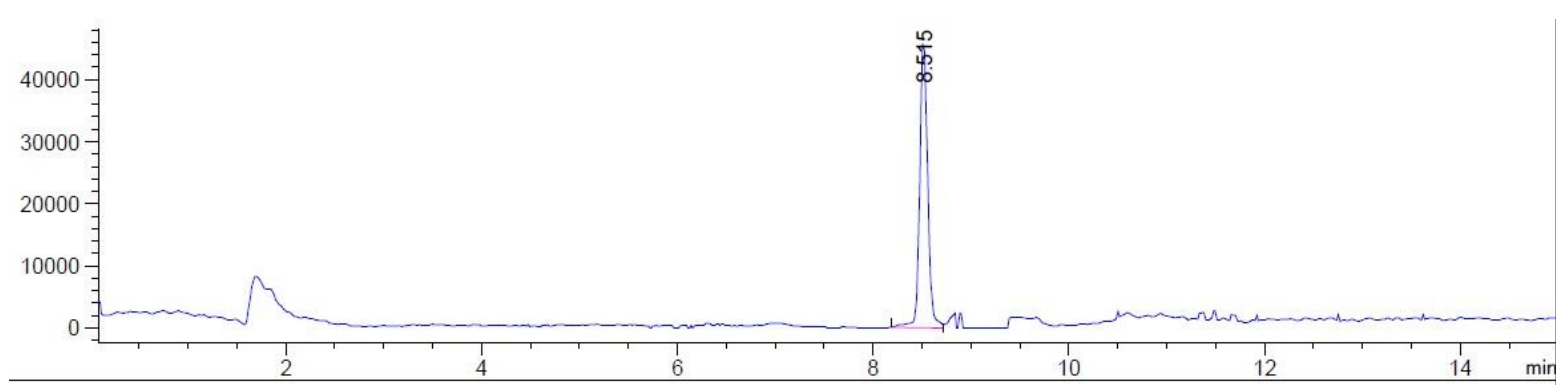

Fig. 8. Chromatogram of alanine (WPPSC of Pleurotus ostreatus fungus)

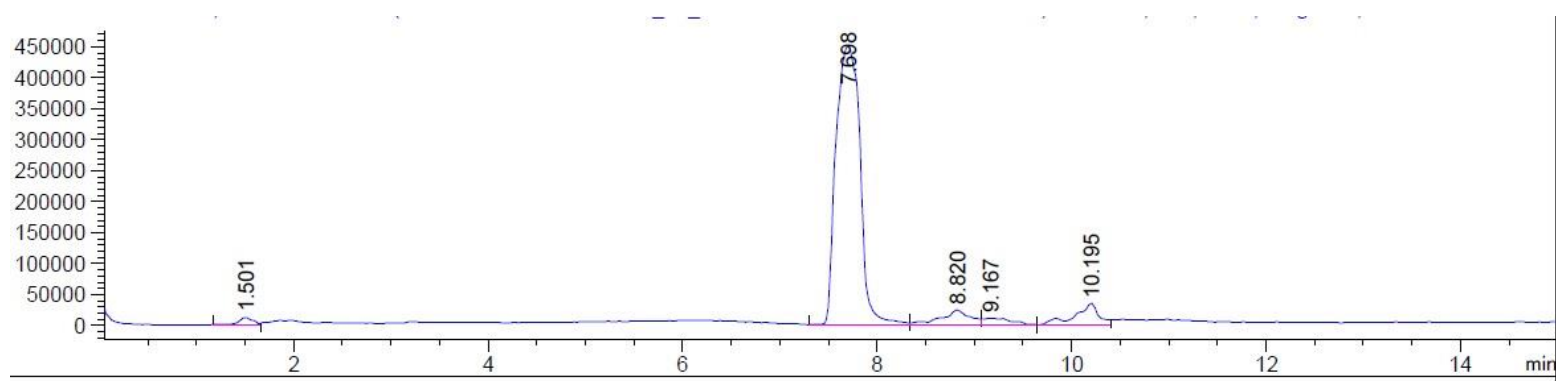

Fig. 9. Chromatogram of phenylalanine (comparison solution)

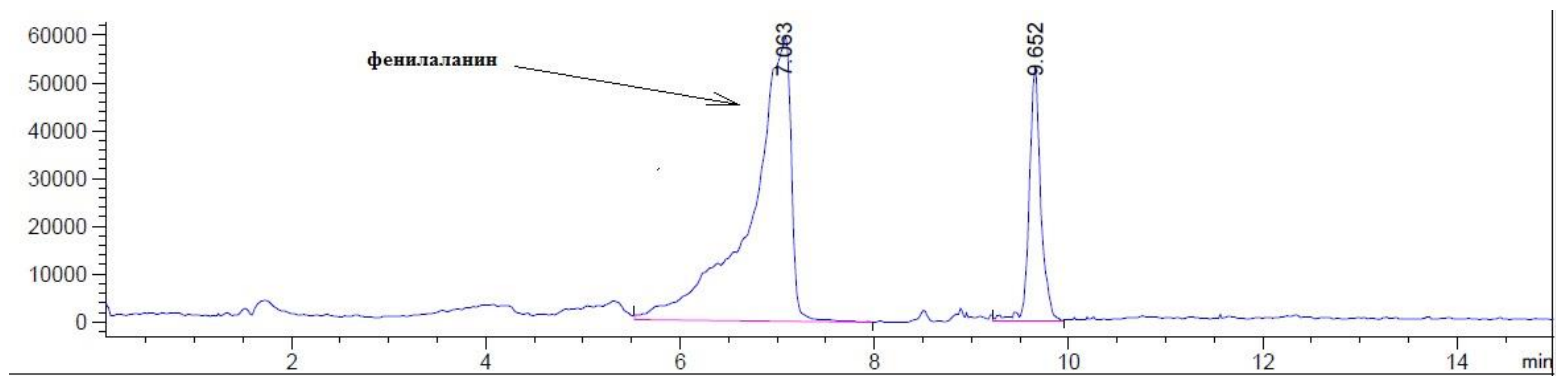

Fig. 10. Chromatogram of phenylalanine (WPPSC of Pleurotus ostreatus fungus)

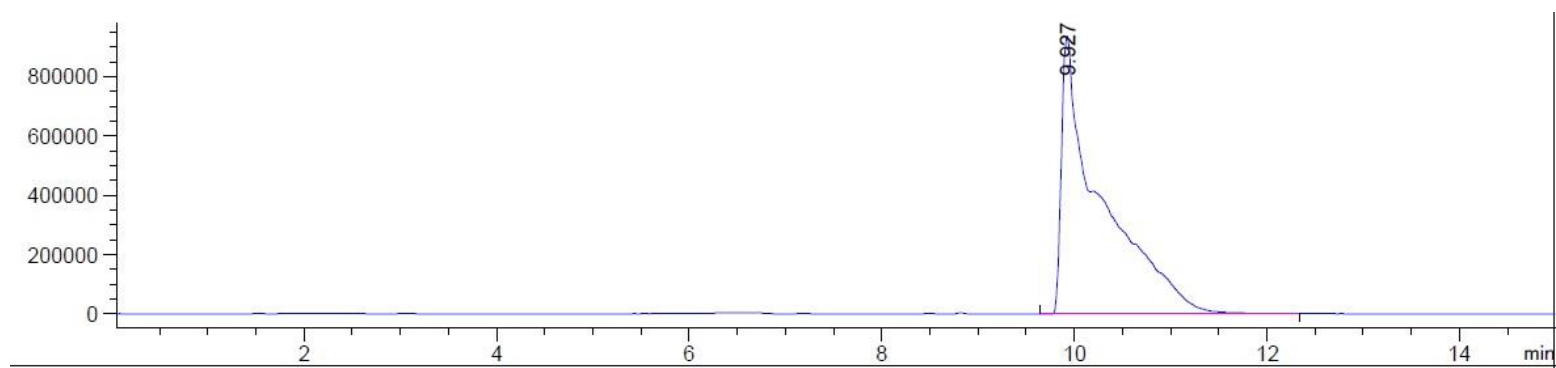

Fig. 11. Chromatogram of lysine (comparison solution)

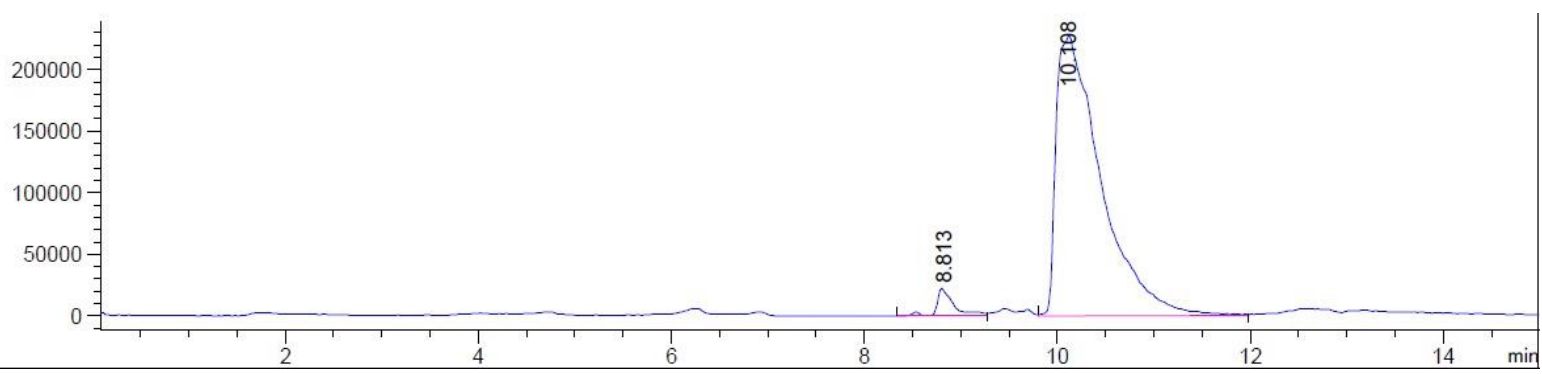

Fig. 12. Chromatogram of lysine (WPPSC of Pleurotus ostreatus fungus) 


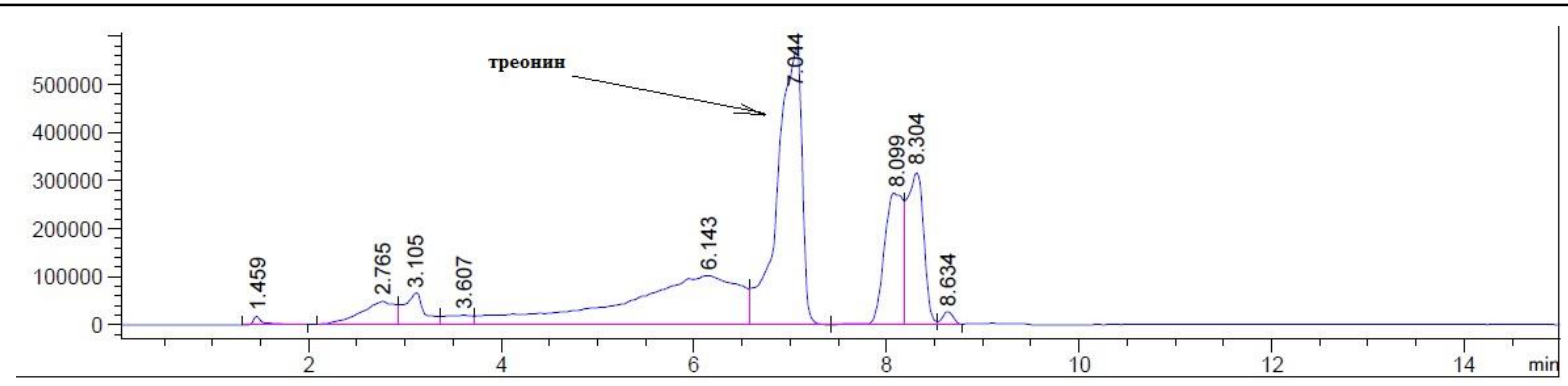

Fig. 13. Chromatogram of threonine (comparison solution)

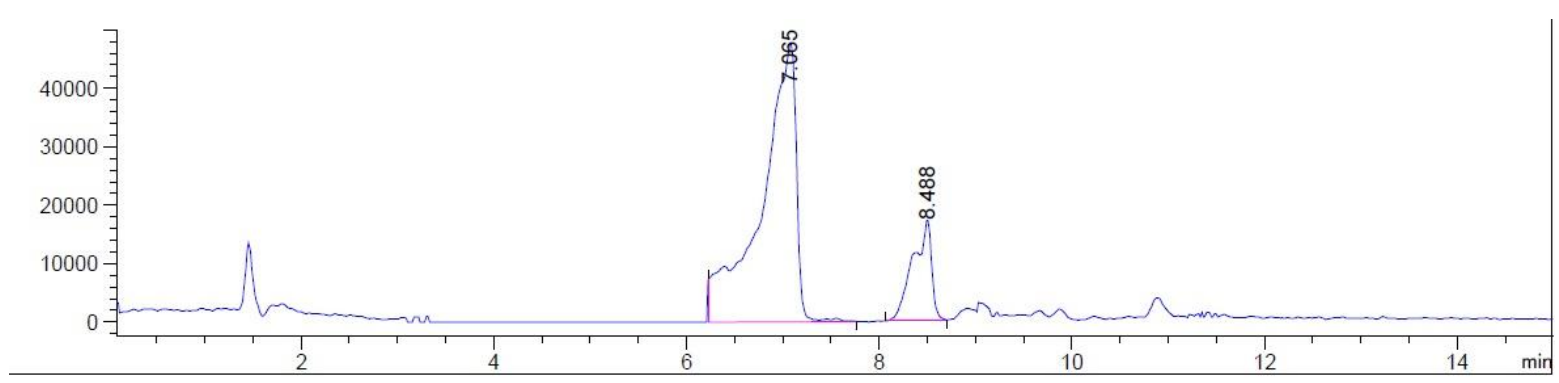

Fig. 14. Chromatogram of threonine (WPPSC of Pleurotus ostreatus fungus)

The study of the amino acid composition of the WPPSC of Pleurotus ostreatus fungus showed that about $7 \%$ of free amino acids contained in the test sample, represented by 10 amino acids, of which 5 are essential. Analyzing the obtained results, it can be concluded that the composition of the WPPSC is dom- inated by the substitutable amino acids $(92.32 \mathrm{mg} / \mathrm{g})$, among which the greatest part is occupied by histidine, sulfur and arginine.

The essential amino acids are occupy $45.74 \mathrm{mg} / \mathrm{g}$ and are mainly represented by lysine, threonine and phenylalanine. The results are shown in the Table. 1

Table 1

The ratio of the composition of the substitutable and essential amino acids

\begin{tabular}{|c|c|c|c|}
\hline \multicolumn{2}{|c|}{ Substitutable amino acids } & \multicolumn{2}{c|}{ Essential amino acids } \\
\hline Name of the amino acid & $\mathrm{mg} / \mathrm{g}$ of studied sample & Name of the amino acid & $\mathrm{mg} / \mathrm{g}$ of studied sample \\
\hline Arginine & 15.8 & Phenylalanine & 13.06 \\
\hline Glycine & 4.22 & Lysine & 16.62 \\
\hline Histidine & 40.34 & Threonine & 2.4 \\
\hline Serine & 24.38 & Leucine and isoleucine & \\
\hline Alanine & 7.58 & & 45.74 \\
\hline Sum & 92.32 & Sum & \\
\hline
\end{tabular}

The whole complex of amino acids is represented by aliphatic, heterocyclic and aromatic compounds. The largest percentage of the sum of identified amino acids belongs to compounds of the aliphatic structure. This group includes monoamino monocarboxylic amino acids, they are represented by glycine, alanine, leucine and isoleucine, threonine and serine and diaminomonocarbone lysine and arginine. Amino acids of heterocyclic structure are represented by histidine; aromatic - phenylalanine.

\section{Conclusions from the conducted research} and prospects for further development of this field

1. The method of high-performance liquid chromatography has been used to study the composition of free amino acids of the WPPSC of Pleurotus ostreatus fungus.
2. It has been established that WPPSC contains about $7 \%$ of free amino acids. Identified and determined quantitative content of 10 amino acids, among which 5 are essential.

3. The largest percentage of the sum of the identified amino acids belongs to the compounds of the aliphatic structure $(61.32 \%)$. Amino acids of heterocyclic structure occupy $29.22 \%$, aromatic $-9.5 \%$ of the total amounts of free amino acids.

The obtained results can be used for standardization of the substance of the WPPSC of Pleurotus ostreatus in the manufacture of drugs based on it.

Prospective in this direction are further research of the composition of the protein component of the WPPSC.

\section{References}

1. Solodovnychenko N. M., Zhuravlov M. S., Kovalov V. M. Likarska roslynna syrovyna ta fitopreparaty: pos. Kharkiv: Vyd-vo NFAU: Zoloti storinky, 2001. 408 p.

2. Analiticheskaya himiya v sozdanii, standartizacii i kontrole kachestva lekarstvennyh sredstv. Vol. 2: monografiya / V. P. Georgievskiy (Ed.). Kharkiv: «NTMT», 2011. 474 p. 
3. Molitorus H. P. Mushrooms in medicine // Folia Microbiol. 1994. Vol. 39, Issue 2. P. 91-98.

4. Mariappan S., Vinayagam S., Durai M. Phytochemical screening of bioactive compounds from Pleurotus ostreatus (jacq.fr) kumm-an wild edible mushroom // World Journal of Pharmaceutical Research. 2015. Vol. 4, Issue 5. P. 1603-1618.

5. Mowsurni F., Chowdhury M. Oyster Mushroom: Biochemical and Medicinal Prospects // Bangladesh Journal of Medical Biochemistry. 2013. Vol. 3, Issue 1. P. 23-28. doi: https://doi.org/10.3329/bjmb.v3i1.13804

6. TU U 10.8-02010675-001:2017 Kompleks bilkovo-polisakharydnyi.

7. Kucherenko N. V., Martynov A. V., Demianenko V. H. Rozrobka metodyk standartyzatsiyi vodorozchynnoho bilkovopolisakharydnoho kompleksu, otrymanoho z hryba Pleurotus Ostreatus // Farmatsevtychnyi zhurnal. 2008. Issue 1. P. 92-95.

8. Minaieva V. O. Khromatohrafichnyi analiz: pidr. Cherkasy, 2013. 284 p.

9. Peptide and amino acids separation and identification from natural products / Neda I. et. al. // Analytical Chemistry. 2012. Issue 6. P. 135-146. doi: https://doi.org/10.5772/51619

10. Konovalova E. Yu., Stazhyla E. N., Lebeda A. Ph. Amino acid research of family elaeagnaceae juss. Plants' leaves // Fitoterapiya. 2010. Issue 2. P. 60-64.

11. Determination of amino acids in medicinal plants from Southern Sonora, Mexico / Moran-Palacio E. J. et. al. // Tropical Journal of Pharmaceutical Research. 2014. Vol. 13, Issue 4. P. 601-606. doi: https://doi.org/10.4314/tjpr.v13i4.17

12. Sputnik hromatografista. Metody zhidkostnoy hromatografii / Rudakov O. B. et. al. Voronezh: Vodoley, 2004. 528 p.

13. Minazova G. I. Highly effective liquid chromatography in the analysis of natural raw material // Bashkirskiy himicheskiy zhurnal. 2010. Vol. 17, Issue 4. P. 134-136.

14. Aminokisloty glazami himikov, farmacevtov, biologov. Vol. 1 / Syrovaya A. O. et. al. Kharkiv: Shchedra sadiba plyus, 2014. $228 \mathrm{p}$.

15. Davies J. S. Amino Acids, Peptides and Proteins. Cambridge: The Royal Society of Chemistry, 2006. 472 p.

Рекомендовано до публікаиії д-р фарм. наук Каплаушенко А. Г. Дата надходження рукопису 19.06.2018

Boris Varinsky, PhD, Associate Professor, Department of Physical and Colloidal Chemistry. Zaporizhzhia State Medical University, Maiakovskoho ave., 26, Zaporizhzhia, Ukraine, 69035

E-mail: borisav70@yahoo.com

Nataliia Kucherenko, PhD, Associate Professor, Department of Drug Technology, Organization and Economy of Pharmacy, SI “Luhansk State Medical University”, Budivelnykiv str., 32, Rubizhne, Ukraine, 93012

E-mail: tekhnology.kucherenko@gmail.com

Olga Kolpakova, Assistant, Department of Chemical and Pharmaceutical Technologies, Institute of Chemical Technologies of the East Ukrainian National University. V. Dal, Volodymyrska str., 31, Rubizhne, Ukraine, 93009, Postgraduate student, Department of Drug Technology, Organization and Economy of Pharmacy, SI "Luhansk State Medical University”, Budivelnykiv str., 32, Rubizhne, Ukraine, 93012

E-mail: okolpakova91@gmail.com 